ISSN 1678-3921

Journal homepage: www.embrapa.br/pab

For manuscript submission and journal contents, access: www.scielo.br/pab

\section{Genetic parameters and selection indexes for biofortified red leaf lettuce}

\begin{abstract}
The objective of this work was to determine the genetic parameters and the efficiency of different selection indices for biofortified red leaf lettuce (Lactuca sativa var. crispa) lines with agronomic and nutritional potential. The experiment was carried out in a randomized complete block design with three replicates and 31 crisp-textured and red-tinted leaf lettuce genotypes: the Belíssima cultivar, with a low carotenoid content and rich in anthocyanins; and 30 lines from the cross between the Belíssima and Uberlândia 10000 cultivars, rich in carotenoids and with a low anthocyanin content. The assessed traits were: total green mass $(\mathrm{g})$, stem diameter $(\mathrm{cm})$, leaf count, plant diameter (cm), foliar temperature $\left({ }^{\circ} \mathrm{C}\right)$, soil plant analysis development (SPAD) index, anthocyanin content (mg $100 \mathrm{~g} \mathrm{~g}^{-1}$ sample), and bolting (days after sowing). To estimate selection gains, 12 genotypes were selected through selection indices. The traditional index proposed by Smith \& Hazel and the sum of ranks index by Mulamba \& Mock provided the highest selection gains in the biofortified lettuce. The coefficient of genotypic determination for leaf count, anthocyanin content, bolting, and SPAD index is of high magnitude.
\end{abstract}

Index terms: Lactuca sativa, anthocyanin, biofortified food, genetic variability, nonparametric indices.

\section{Parâmetros genéticos e índices de seleção para alface roxa biofortificada}

Resumo - O objetivo deste trabalho foi determinar os parâmetros genéticos e a eficiência de diferentes índices de seleção para linhagens de alface de folhas vermelhas (Lactuca sativa var. crispa) biofortificada e com potencial agronômico e nutricional. $\mathrm{O}$ experimento foi conduzido em delineamento de blocos ao acaso, com três repetições e 31 genótipos de alface do tipo crespa e com pigmentação roxa: a cultivar Belíssima, com baixa quantidade de carotenoides e rica em antocianina; $\mathrm{e} 30$ linhagens provenientes do cruzamento entre as cultivares Belíssima e Uberlândia 10000, rica em carotenoides e com baixo teor de antocianina. As características avaliadas foram: massa verde total $(\mathrm{g})$, diâmetro do caule $(\mathrm{cm})$, número de folhas, diâmetro da planta $(\mathrm{cm})$, temperatura foliar $\left({ }^{\circ} \mathrm{C}\right)$, índice de desenvolvimento de análise de planta de solo (SPAD), teor de antocianina (mg por $100 \mathrm{~g}$ de amostra) e pendoamento (dias após a semeadura). Para as estimativas dos ganhos de seleção, foram selecionados 12 genótipos por meio de índices de seleção. $\mathrm{O}$ índice clássico proposto por Smith \& Hazel e o índice da soma de "ranks" de Mulamba \& Mock proporcionaram os maiores ganhos de seleção na alface biofortificada. O coeficiente de determinação genotípica para número de folhas, teor de antocianina, pendoamento e índice SPAD é de alta magnitude.

Termos para indexação: Lactuca sativa, antocianina, alimento biofortificado, variabilidade genética, índices não paramétricos. 


\section{Introduction}

Lettuce (Lactuca sativa L.) is the most consumed leafy vegetable in Brazil and it is a rich source of fibers, carotenoids, phenolic compounds, antioxidants, minerals, and vitamins A, C, and K (Sytar et al., 2018). However, there is a demand for lettuce with a higher nutritional quality due to changes in the eating habits of the population and a greater concern for health (Chopra et al., 2020).

Plant breeding has provided great advances in the lettuce crop, such as lettuce cultivars adapted to tropical conditions and rich in carotenoids (Cassetari et al., 2015; Maciel et al., 2019a, 2019b). However, the search for an individual that combines several characteristics requires an increased selection complexity since lettuce lines have been mainly selected by the univariate analysis (Ceccherini et al., 2020), which results in a product selected according to a response variable per se. In view of these constraints, methods are needed to increase the efficiency and the success of lettuce breeding programs. An alternative is the simultaneous trait assessment using nonparametric indices (Bizari et al., 2017; Silva et al., 2020). Moreover, the estimates of genetic parameters, as coefficient of genotypic determination and genetic gain, and the correlation between traits are reliable indicators of the enhancement of a characteristic of a given genetic material through selection.

Although several studies have shown the efficiency of selection index methods in understanding the direct and indirect relationship between agronomically important variables and in selecting superior lines (Vieira et al., 2017; Silva et al., 2020), there are no known researches on biofortified lettuce germplasm.

The objective of this work was to determine the genetic parameters and the efficiency of different selection indices for biofortified red leaf lettuce (Lactuca sativa var. crispa) lines with agronomic and nutritional potential.

\section{Materials and Methods}

The experiment was conducted at the vegetables research station of Universidade Federal de Uberlândia (UFU), located in the state of Minas Gerais, Brazil (1842'43.19'S, 47²9'55.8'W, at 873 $\mathrm{m}$ above sea level), in 2018. The experiment was arranged in a randomized complete block design with three replicates and 31 treatments (genotypes). The assessed genotypes were: the Belíssima cultivar (control), with a low carotenoid content and rich in anthocyanin content; and 30 lines of red leaf lettuce, obtained from the cross between cultivars Belíssima and Uberlândia 10000, rich in carotenoids (Sousa et al., 2007) and with a low anthocyanin content, after six successive self-pollination procedures from 2013 to 2017. The lines are part of the biofortified lettuce breeding program of UFU, and all genealogy was stored in the BG a BIOFORT software, under patent number BR512019002403-6 of Instituto Nacional da Propriedade Industrial (Maciel et al., 2019a).

Sowing was carried out on March 28, 2018. The seedlings were grown in 200 cell EPS trays with commercial coconut fiber substrate (Carolina Soil Company, Inc., Kingston, NC, USA). After sowing, the trays were placed in an arch-type greenhouse (5 $\mathrm{m}$ wide, $6 \mathrm{~m}$ long, and $3.5 \mathrm{~m}$ high), which was covered with UV-resistant, $150 \mu \mathrm{m}$ transparent polyethylene film, and a white anti-aphid side screen. At 29 days after sowing, the lettuce seedlings were transplanted to the definitive field seedbeds, which were $1.30 \mathrm{~m}$ long and were tilled using a rototiller.

The soil was classified as an Oxisol (Soil Survey Staff, 2014) and showed the following characteristics in the $0-20 \mathrm{~cm}$ layer: $>50 \%$ clay texture, $\mathrm{pH}\left(\mathrm{CaCl}_{2}\right)$ 4.9, $3.9 \mathrm{dag} \mathrm{kg}^{-1}$ organic matter, $79.1 \mathrm{mg} \mathrm{dm}^{-3} \mathrm{P}$ (rem), $0.29 \mathrm{cmol}_{\mathrm{c}} \mathrm{dm}^{-3} \mathrm{~K}, 3.3 \mathrm{cmol}_{\mathrm{c}} \mathrm{dm}^{-3} \mathrm{Ca}, 1.3 \mathrm{cmol}_{\mathrm{c}} \mathrm{dm}^{-3}$ $\mathrm{Mg}, 4.9 \mathrm{cmol}_{\mathrm{c}} \mathrm{dm}^{-3} \mathrm{H}+\mathrm{Al}$, sum of bases of $4.90 \mathrm{cmol}_{\mathrm{c}}$ $\mathrm{dm}^{-3}$, cation exchange capacity of $9.80 \mathrm{cmol}_{\mathrm{c}} \mathrm{dm}^{-3}$, and base saturation of $50 \%$. Crop handling, such as sowing, transplanting, irrigation, fertilization, and pest and disease control, followed the procedures for the lettuce crop (Filgueira, 2013).

The experimental plots consisted of 16 plants, which were distributed in four rows per seedbed, distant $0.25 \times 0.25 \mathrm{~m}$ from each other. The eight middle plants were assessed. The plants were harvested 35 days after transplanting and taken to the laboratory. Then, the following traits were evaluated: total green mass (g), by weighing all outer leaves; stem diameter (cm), measured with calipers; commercial leaf count, by counting the number of leaves longer than $5 \mathrm{~cm}$; plant diameter $(\mathrm{cm})$; foliar temperature $\left({ }^{\circ} \mathrm{C}\right)$, measured with the $4000.4 \mathrm{GL}$ infrared thermometer (Everest Interscience Inc., Chino Hills, CA, USA), by pointing the device sensor to the center of the leaf surface of 
the sampled outer leaves; bolting, counted in days after sowing; total anthocyanin content (mg $100 \mathrm{~g} \mathrm{~g}^{-1}$ sample); and soil plant analysis development (SPAD) index. The two latter traits were obtained as follows.

Total anthocyanin content was measured using the method of Francis (1982). The concentration of anthocyanin pigments was determined by absorbance, according to the equation: At $=(|\mathrm{Abs}| \mathrm{f}) / \varepsilon$, where At represents the anthocyanins (mg anthocyanin in $100 \mathrm{~g}^{-1}$ fresh mass); Abs is absorbance; $\mathrm{f}$ is the dilution factor; and $\varepsilon$ is the molar attenuation coefficient of cyanidin (98.2) related to the red color associated with the anthocyanin content present in the lettuce leaves (Zhang et al., 2016).

The SPAD index (Cassetari et al., 2015) was calculated using the mean value of the data from the four middle plants of each plot obtained with the SPAD502 handheld chlorophyll meter (Konica Minolta, Ramsey, NJ, USA). The days until the flower stalk appeared were also counted. Since the chlorophyll content has a high correlation with the concentration of carotenoids in lettuce, it was used to assess the amount of carotenoids in lettuce leaves through the SPAD index (Cassetari et al., 2015; Maciel et al., 2019b).

The analysis of variance was performed for all lettuce lines evaluated in order to obtain the mean squares of the assessed traits and the coefficient of variation $(\mathrm{CV})$.

The coefficient of genetic variation $(\mathrm{CVg})$, the ratio $(\mathrm{CVg} / \mathrm{CVe})$ between the $\mathrm{CVg}$ and the coefficient of experimental variation (CVe), and the coefficient of genotypic determination $\left(\mathrm{H}^{2}\right)$ for each variable were also calculated. $\mathrm{H}^{2}$ was given by the following equation: $\mathrm{H}^{2}=(\varnothing \mathrm{g} / \varnothing \mathrm{f})=[\varnothing \mathrm{g} /(\mathrm{MSG} / \mathrm{r})]$ where $\mathrm{H}^{2}$ is the coefficient of genotypic determination, $\varnothing \mathrm{g}$ is the genetic variability between the studied lettuce lines, MSG is the mean square of the genotype, and $r$ is the number of replicates.

Both the phenotypic (rf) and the genotypic (rg) correlations, as well as the selection indices for the traits that showed a significant result in the analysis of variance, were determined. The following equations were used to calculate the phenotypic and genotypic correlations, respectively,

$$
r_{f}=\frac{\mathrm{TMP}_{\mathrm{xy}}}{\sqrt{\mathrm{TMS}_{\mathrm{x}} * \mathrm{TMS}} \mathrm{S}_{\mathrm{y}}} \text { and } r_{\mathrm{g}}=\frac{\hat{\sigma}_{\mathrm{gxy}}}{\sqrt{\hat{\sigma}_{\mathrm{gx}}^{2} * \hat{\sigma}_{\mathrm{gy}}^{2}}}
$$

where TMP is the treatment mean product; TMS is the treatment mean square; $\mathrm{x}$ and $\mathrm{y}$ are the analyzed traits; $\hat{\sigma}_{\text {gxy }}$ is the genotypic covariance estimator between $\mathrm{x}$ and $\mathrm{y}$; and $\bar{\sigma}_{\mathrm{gx}}^{2}$ and $\widehat{\sigma}_{\mathrm{gy}}^{2}$ are the genotypic variance estimators of $\mathrm{x}$ and $\mathrm{y}$, respectively (Cruz et al., 2014).

To estimate selection gains, 12 genotypes $(38.70 \%$ of the studied genotypes) were selected using the following methods: direct and indirect selection (Cruz et al., 2014), the traditional selection index of Smith (1936) and Hazel (1943), the sum of ranks index of Mulamba \& Mock (1978), and the base index of Willians (1962). The estimate gain via direct selection (Cruz et al., 2014) at the $\mathrm{i}$-th trait $\left(\mathrm{SG}_{\mathrm{i}}\right)$ was obtained by: $\mathrm{SG}_{\mathrm{i}}=\left(\mathrm{X}_{\mathrm{si}}-\mathrm{X}_{\mathrm{oi}}\right) \mathrm{h}_{\mathrm{i}}{ }_{\mathrm{i}}=\mathrm{DS}_{\mathrm{ih}} \mathrm{h}^{2}{ }_{\mathrm{i}}$, where $\mathrm{X}_{\mathrm{si}}$ is the mean of the lines selected for trait $i, X_{o i}$ is the original population mean, $\mathrm{DS}_{\mathrm{i}}$ is the population selection differential, and $\mathrm{h}^{2}{ }_{\mathrm{i}}$ is the coefficient of genotypic determination of trait $i$.

The indirect gain (Cruz et al., 2014) for trait $\mathrm{j}$, by selecting trait $\mathrm{i}$, was given by $\mathrm{SG}_{\mathrm{j}(\mathrm{i})}=\mathrm{DS}_{\mathrm{j}(\mathrm{i})} \mathrm{h}^{2}$, where $\mathrm{DS}_{\mathrm{j}(\mathrm{i})}$ is the indirect selection differential from the mean of the traits of the individuals whose superiority has been highlighted by another trait to which direct selection was applied.

The traditional selection index of Smith (1936) and Hazel (1943) was estimated by the linear combination of the assessed traits, through the selection index (I) and the aggregate genotype $(\mathrm{H})$, as follows:

$$
\begin{aligned}
& I=b_{1} y_{1}+b_{2} y_{2}+\cdots+b_{n} y_{n}=\sum_{i=1}^{n} b_{i} y_{i}=y^{\prime} b \\
& H=a_{1} g_{1}+a_{2} g_{2}+\cdots+a_{n} g_{n}=\sum_{i=1}^{n} a_{i} g_{i}=g^{\prime} a
\end{aligned}
$$

where $\mathrm{n}$ is the number of traits analyzed, $\mathrm{b}$ is the $1 \mathrm{xn}$ vector for the weighting factors of the selection index to be estimated, $y^{\prime}$ is the nxp matrix for the phenotypic values of the traits, $\mathrm{a}$ is the $1 \mathrm{xn}$ vector for the economic weights previously established, and $g$ is the $n x p$ matrix for the unknown genetic values of the $n$ traits in question; $p$ is the number of families or progenies analyzed.

The nxn matrix for phenotypic variances and covariances is represented by $\mathrm{P}$. The nxn matrix for the genetic covariances of the traits is given by G. Vector $b$ is estimated by $b=\mathrm{P}^{-1} \mathrm{Ga}$, where $\mathrm{P}^{-1}$ is the phenotypic variance-covariance inverse matrix of the traits. The expectedgain for traitjwascalculated by: $\Delta \mathrm{g}_{\mathrm{j}(\mathrm{I})}=\mathrm{DS}_{\mathrm{j}(\mathrm{I})} \mathrm{h}_{\mathrm{j}}{ }_{\mathrm{j}}$, 
where $\Delta g_{j(I)}=g_{j(I)}$ is the expected gain for trait $\mathrm{j}$, for selection based on index I; $\mathrm{DS}_{\mathrm{j}(\mathrm{I})}$ is the selection differential of trait $\mathrm{j}$, for selection based on index I; and $\mathrm{h}_{\mathrm{j}}^{2}$, is the heritability of trait $\mathrm{j}$.

The sum of ranks index (Mulamba \& Mock, 1978) includes both genotypic and phenotypic variance and covariance estimates, and also assigns economic weights to the studied traits (Cruz et al., 2014). This index arranges the genotypes by assigning higher absolute values to those with a better performance, considering each analyzed trait. After that, the rank number of each genotype related to each studied trait is added up, resulting in the selection index, as follows: $\mathrm{I}=\mathrm{r}_{1}+\mathrm{r}_{2}+\ldots+\mathrm{r}_{\mathrm{n}}$, where $\mathrm{I}$ is the index value for a given individual or family; $r_{j}$ is the rank of an individual related to the $j$-th variable; and $n$ is the number of variables the index includes. The method can assign different weights to rank the variables, according to the breeder's specifications. For this reason, the economic weights were given by: $I=p_{1} r_{1}+p_{2} r_{2}+\ldots+p_{n} r_{n}$, where $\mathrm{p}_{\mathrm{j}}$ is the economic weight assigned to the $\mathrm{j}$-th trait.

The base index of Willians (1962) is given by the linear combination of the mean phenotypic values of the traits that are weighted by their respective economic weights. The index is obtained by:

$$
\mathrm{I}=\mathrm{a}_{1} \mathrm{y}_{1}+\mathrm{a}_{2} \mathrm{y}_{2}+\cdots+\mathrm{a}_{\mathrm{n}} \mathrm{y}_{\mathrm{n}}=\sum_{\mathrm{i}=1}^{\mathrm{n}} \mathrm{a}_{\mathrm{i}} \mathrm{y}_{\mathrm{i}}=\mathrm{y}^{\prime} \mathrm{a},
$$

where $y$ is the mean, and a is the economic weight for the analyzed traits.

The selection criteria for all indices comprised the increase in green mass, stem diameter, leaf count, SPAD index, and bolting, as well as the decrease in plant diameter. The economic weight was considered the coefficient of genetic variation of each variable, according to Cruz et al. (2014). The Genes, version 2015.5.0, software (Cruz, 2013) was used in the statistical analysis.

\section{Results and Discussion}

The lettuce lines showed genetic variability in the traits leaf count, plant diameter, SPAD index, total anthocyanin (ANTH) content, and bolting at $1 \%$ probability and total green mass at $5 \%$ probability by the F-test, indicating the possibility of selecting superior lines for genetic breeding (Table 1). However, the lettuce genotypes did not differ for stem diameter and foliar temperature. Therefore, these two last traits were not included in the remaining analyses, as they did not provide genetic gains for superior genotype selection (Cruz et al., 2014).

The coefficient of genetic variation $(\mathrm{CVg})$ confirmed genetic variability. The higher $\mathrm{CVg}$ estimates were those for total green mass and ANTH, which showed, among all analyzed variables, the highest genetic variability, allowing selection. This result indicates that the studied genotypes are promising in the screening of anthocyanin-rich superior lines. Other authors working with lettuce also reported high $\mathrm{CVg}$ values for green mass (Azevedo et al., 2014; Peixoto et al., 2020). The obtained results, therefore, indicate a greater prospect of genetic progress with selection.

The CVe of the evaluated variables varied between $4.87 \%$ for bolting and $50.87 \%$ for green mass, being the highest for green mass and stem diameter. These characteristics are probably highly influenced by uncontrolled environmental factors that normally occur in field experiments (Pinto et al., 2017), making the selection of superior genotypes more complex. In the present study, $37.5 \%$ of the variables showed a low CVe and $25 \%$ of them a medium one according to Pimentel-Gomes (2009), pointing to the high experimental precision and low residual error value in the analysis of variance. In other works carried out with lettuce, lower CVe values were reported for total green mass and stem diameter (Azevedo et al., 2014; Peixoto et al., 2020). This difference can be attributed to the different environmental conditions in which the experiment was conducted and also to the characterized genotypes.

The $\mathrm{CVg} / \mathrm{CVe}$ ratio showed values higher than the unit for the variables leaf count, ANTH, bolting, and SPAD index (Table 1). These results are indicative of the possibility of obtaining red-tinted leaf lettuce lines that are biofortified and tolerant to early bolting. A $\mathrm{CVg} / \mathrm{CVe}$ ratio value greater than or equal 1 indicates that the available genetic variation is the main cause of the variation in the estimates of the experimental data (Leite et al., 2016). The result obtained in the present work is indicative of a more favorable condition for the phenotypic selection of these characters. Likewise, Azevedo et al. (2014) observed values greater than 1 for the $\mathrm{CVg} / \mathrm{CVe}$ ratio for leaf count and bolting. This result is indicates a greater possibility of genetic gain 
for the studied characters, being promising for genetic improvement.

The $\mathrm{H}^{2}$ results varied according to the analyzed traits, and the values over 0.70 were considered of high magnitude (Ramalho et al., 2012). The variables with a $\mathrm{CVg} / \mathrm{CVe}$ ratio higher than 1 - leaf count, ANTH, bolting, and SPAD index - also showed high $\mathrm{H}^{2}$ values (Table 1). This result points to a chance of success in selecting plants based on their phenotype and a greater chance of obtaining lettuce plants with a high leaf count, ANTH, late bolting, and higher SPAD index. Other authors working with lettuce also found high $\mathrm{H}^{2}$ values for the same variables, except for ANTH (Azevedo et al., 2014; Peixoto et al., 2020). This data confirms the possibility of success in advancing generations to improve the abovementioned characteristics.

In addition, the high $\mathrm{H}^{2}$ estimates obtained in the present work show the predominance of genetic over environmental variability, indicating favorable conditions for the selection and genetic improvement of the evaluated genotypes. Other researchers also found high $\mathrm{H}^{2}$ values for the lettuce traits leaf count (Azevedo et al., 2014; Oliveira et al., 2019; Silva et al., 2019) and ANTH content (Oliveira et al., 2019). These results confirm the possibility of obtaining red-tinted leaf lettuce lines rich in ANTH and with a higher leaf count.

A positive genotypic and phenotypic correlation was observed between: total green mass and leaf count, total green mass and plant diameter, leaf count and plant diameter, leaf count and bolting, plant diameter and SPAD index, and SPAD index and ANTH content (Table 2). In view of these results, it is possible to infer that leaf count promotes an increase in green mass and plant diameter, besides positively affecting bolting. The greater number of leaves and increased time for bolting are desirable characteristics in lettuce. According to Peixoto et al. (2020), lettuce plants with a higher leaf count enable later bolting, a feature that increases the marketing period of the product.

Leaf count is a major characteristic for both the farmer and market, since it indicates the adaptation of the genetic material to the environment. This trait can be influenced by the farming site and the genetic component (Diamante et al., 2013). Researchers have observed that the lettuce genotypes with the highest leaf count also showed a greater plant diameter (Diamante et al., 2013; Ceccherini et al., 2020). Therefore, it is expected that plants with a higher number of leaves have a larger diameter and present later bolting.

Overall, the values for the genotypic and phenotypic correlations were close (Table 2), indicating a lower influence of environmental factors and a greater one of genetic factors on the expression of traits. Similar results were observed in other studies carried out with the lettuce crop (Thakur et al., 2016; Peixoto et al., 2020). These authors reported close values for genotypic and phenotypic correlations. The slight difference between the estimates of genotypic and phenotypic correlations

Table 1. Mean squares, coefficients of variance, and genetic parameters of the variables analyzed in red leaf lettuce (Lactuca sativa var. crispa) lines ${ }^{(1)}$.

\begin{tabular}{|c|c|c|c|c|c|c|}
\hline Variable & GMS & $\mathrm{H}^{2}(\%)$ & $\mathrm{CVg}(\%)$ & $\mathrm{CVg} / \mathrm{CVe}$ & $\mathrm{CVe}(\%)$ & ASR \\
\hline GM & $1478.7579^{*}$ & 41.19 & 24.58 & 0.48 & 50.87 & 869.6318 \\
\hline $\mathrm{SD}$ & $0.2789^{\text {ns }}$ & - & - & - & 40.29 & 0.4002 \\
\hline LC & $30.6663^{* *}$ & 76.46 & 17.46 & 1.04 & 16.78 & 7.2181 \\
\hline PD & $36.2838^{* *}$ & 64.32 & 13.28 & 0.78 & 17.13 & 12.9448 \\
\hline FT & $1.4892^{\mathrm{ns}}$ & - & - & - & 6.37 & 2.4188 \\
\hline SPAD & $139.7560^{* *}$ & 97.65 & 20.76 & 3.72 & 5.58 & 3.2832 \\
\hline ANTH & $371.5967^{* *}$ & 81.55 & 32.79 & 1.21 & 27.01 & 68.5491 \\
\hline BOLT & $165.2882^{* *}$ & 88.85 & 7.93 & 1.63 & 4.87 & 18.4376 \\
\hline \multicolumn{7}{|c|}{ Degrees of freedom } \\
\hline \multicolumn{2}{|c|}{ Block } & \multicolumn{3}{|c|}{ Treatment } & \multicolumn{2}{|c|}{ Residue } \\
\hline \multicolumn{2}{|c|}{2} & \multicolumn{3}{|c|}{30} & \multicolumn{2}{|c|}{60} \\
\hline
\end{tabular}

${ }^{(1)} \mathrm{GM}$, green mass (g); SD, stem diameter (cm); LC, leaf count; PD, plant diameter (cm); FT, foliar temperature $\left({ }^{\circ} \mathrm{C}\right)$; SPAD, soil plant analysis development index; ANTH, total anthocyanin content (mg $100 \mathrm{~g}^{-1}$ sample); BOLT, bolting (days after sowing); GMS, genotype mean square; $\mathrm{H}^{2}$, coefficient of genotypic determination; $\mathrm{CVg}$, coefficient of genetic variation; CVe, coefficient of experimental variation; and ASR, average square of the residue. **

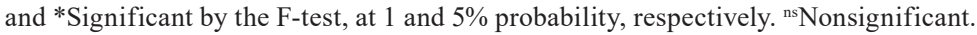


shows how environmental factors impact the analyzed traits (Thakur et al., 2016). The results obtained in the present work suggest success in the breeding program, aiming at the selection of biofortified lettuce, tolerant to early bolting and with good agronomic characteristics.

Direct selection provides maximum gains in a single trait to which the breeder applies selection (Cruz, 2013; Cruz et al., 2014). However, the associations between the studied traits and other variables may result in favorable or unfavorable gains in the secondary traits not included in the selection process (Cruz, 2013). The highest gains by direct selection were obtained for ANTH, SPAD index, green mass, and leaf count; these variables also showed the highest total gain values, in this order: SPAD index, ANTH, green mass, and leaf count (Table 3). Peixoto et al. (2020), studying curly green lettuce, also observed the highest direct gains in green mass, leaf count, and SPAD index. However, as these characteristics can be influenced by other ones, selection indexes are essential for their simultaneous and joint analysis.

The variable bolting showed the lowest individual gain by direct selection (Table 3), matching its low $\mathrm{CVg}$, as well as the lowest total gain (Table 1). This result indicates that the studied lines had close values for the early bolting character, presenting low genetic variability. This promotes selection gain, enabling genetic improvement and the choice of superior

Table 2. Genotypic (G) and phenotypic (F) correlations for six traits assessed in red leaf lettuce (Lactuca sativa var. crispa) lines.

\begin{tabular}{|c|c|c|c|c|c|c|c|}
\hline Character $^{(1)}$ & & GM & $\mathrm{LC}$ & PD & SPAD & ANTH & BOLT \\
\hline \multirow{2}{*}{ GM } & G & 1.00 & $0.62^{+}$ & $0.86^{++}$ & 0.34 & 0.08 & 0.09 \\
\hline & F & 1.00 & $0.67^{* *}$ & $0.85^{* *}$ & 0.21 & -0.60 & -0.07 \\
\hline \multirow{2}{*}{ LC } & G & & 1.00 & $0.66^{++}$ & 0.35 & -0.03 & $0.62^{++}$ \\
\hline & $\mathrm{F}$ & & 1.00 & $0.70^{* *}$ & 0.30 & -0.09 & $0.46^{* *}$ \\
\hline \multirow{2}{*}{ PD } & G & & & 1.00 & $0.60^{++}$ & $0.47^{+}$ & 0.01 \\
\hline & $\mathrm{F}$ & & & 1.00 & $0.47^{* *}$ & 0.24 & -0.08 \\
\hline \multirow{2}{*}{ SPAD } & G & & & & 1.00 & $0.82^{++}$ & 0.005 \\
\hline & F & & & & 1.00 & $0.73^{* *}$ & 0.01 \\
\hline \multirow[t]{2}{*}{ ANTH } & G & & & & & 1.00 & -0.19 \\
\hline & $\mathrm{F}$ & & & & & 1.00 & -0.11 \\
\hline \multirow[t]{2}{*}{ BOLT } & G & & & & & & 1.00 \\
\hline & $\mathrm{F}$ & & & & & & 1.00 \\
\hline
\end{tabular}

${ }^{(1)} \mathrm{GM}$, green mass (g); LC, leaf count; PD, plant diameter (cm); SPAD, soil plant analysis development index; ANTH, total anthocyanin content (mg $100 \mathrm{~g}^{-1}$ sample); and BOLT, bolting (days after sowing). ${ }^{* *}$ and ${ }^{*}$ Significant phenotypic correlation by the t-test, at 1 and $5 \%$ probability, respectively. ${ }^{++}$and ${ }^{+}$Significant genotypic correlation by the bootstrap method with 5,000 simulations, at 1 and 5\% probability, respectively.

Table 3. Estimates of selection gains by direct and indirect selection for six traits assessed in red leaf lettuce (Lactuca sativa var. crispa) genotypes.

\begin{tabular}{|c|c|c|c|c|c|c|}
\hline \multirow{2}{*}{ Variable $^{(1)}$} & \multicolumn{6}{|c|}{ Selection gain (\%) } \\
\hline & GM & $\mathrm{LC}$ & PD & SPAD & ANTH & BOLT \\
\hline GM & 15.61 & 9.37 & -13.64 & 2.26 & -3.73 & 0.0 \\
\hline LC & 8.47 & 15.27 & -9.17 & 3.83 & -4.36 & 8.6 \\
\hline PD & 8.96 & 5.83 & -9.97 & 4.06 & 1.37 & 0.02 \\
\hline SPAD & 0.21 & 2.78 & -9.07 & 20.41 & 13.14 & -0.46 \\
\hline ANTH & -3.65 & -11.00 & -9.50 & 20.90 & 29.88 & -8.17 \\
\hline BOLT & -1.31 & 3.75 & 0.79 & 0.20 & -1.26 & 7.53 \\
\hline Total & 28.29 & 26.00 & -50.56 & 51.66 & 35.04 & 7.52 \\
\hline
\end{tabular}

${ }^{(1)} \mathrm{GM}$, green mass (g); LC, leaf count; PD, plant diameter (cm); SPAD, soil plant analysis development index; ANTH, total anthocyanin content (mg 100 $\mathrm{g}^{-1}$ sample); and BOLT, bolting (days after sowing). 
individuals. The average values for early bolting of the genotypes characterized in the present work can be found in the study by Maciel et al. (2019b).

The direct selection of leaf count contributed to indirect gains in green mass, plant diameter, SPAD index, and bolting; however, the method resulted in a negative gain in ANTH content (Table 3). In Brazil, lettuce is usually sold in a plastic or wooden box, almost without any cooling method that could maintain product quality (Sala \& Costa, 2012); therefore, plants with a small plant diameter are preferable to reduce quality losses during packaging. Maciel et al. (2019b), analyzing the same genotypes of the present work, found lower values for plant diameter than other authors (Diamante et al., 2013; Santi et al., 2013). The direct selection for the SPAD index provided indirect gains in green mass, leaf count, plant diameter, ANTH content, and bolting (Table 3). This was the best indirect selection strategy, for it provided a small plant diameter, positive gains in the rest of the analyzed traits, and the highest total gain. However, Peixoto et al. (2020) reported that direct selection for the SPAD index reduced green mass and plant diameter; this difference in results can be attributed to the characterized genotypes.
Differently from direct selection, which promotes maximum gains in the characteristic that is being selected by the breeder, selection indices allow to perform the simultaneous selection of several economically important traits, increasing the chances of success in genetic breeding (Bizari et al., 2017). The used indices also allow several combinations based on the experimental unit (Cruz et al., 2014). Therefore, the success in the selection of superior lettuce genotypes in terms of biofortification and agronomic potential is greater.

The index of Smith (1936) and Hazel (1943) provided the highest total gain, followed by the index of Mulamba \& Mock (1978). Both indices provided all the analyzed traits with positive gains (Table 4). The index of Willians (1962) resulted in the lowest total gain and in a negative gain in bolting, being considered as an inefficient method because it provided the highest plant diameter gains and reduced bolting. The index of Smith (1936) and Hazel (1943) provided the highest SPAD index and ANTH gains, and showed $75 \%$ of similarity among the selected genotypes, compared with the direct selection for the SPAD index (Table 5). In other researches, there was an increase in the analyzed characteristics when using the index of

Table 4. Estimates of selection gains in red leaf lettuce (Lactuva sativa var. crispa) genotypes by the traditional index of Smith \& Hazel (SH), the sum of ranks index of Mulamba \& Mock (MM), and the base index of Willians (W) ${ }^{(1)}$.

\begin{tabular}{lccccccc}
\hline \multirow{2}{*}{ Index } & \multicolumn{7}{c}{ Selection gain (\%) } \\
\cline { 2 - 7 } & GM & LC & PD & SPAD & ANTH & BOLT & Total \\
\hline SH & 5.66 & 6.91 & 5.67 & 19.70 & 22.26 & 1.35 & 61.55 \\
MM & 5.57 & 8.31 & 6.06 & 17.02 & 20.53 & 2.10 & 59.59 \\
W & 12.03 & 7.61 & 8.27 & 12.13 & 16.22 & -0.42 & 55.84 \\
\hline
\end{tabular}

${ }^{(1)} \mathrm{GM}$, green mass (g); LC, leaf count; PD, plant diameter (cm); SPAD, soil plant analysis development index; ANTH, total anthocyanin content (mg 100 $\mathrm{g}^{-1}$ sample); and BOLT, bolting (days after sowing).

Table 5. Indication of 12 superior genotypes of red leaf lettuce (Lactuca sativa var. crispa) selected by direct selection, the traditional index of Smith \& Hazel, the sum of ranks index of Mulamba \& Mock, and the base index of Willians.

\begin{tabular}{ll}
\hline Selection index & \multicolumn{2}{c}{ Selected genotype } \\
\hline \multirow{3}{*}{ Direct selection for SPAD } & UFU-199\#1\#1\#1; UFU-199\#6\#2\#1; UFU-75\#2\#2\#1; UFU-199\#2\#1\#1; UFU-199\#2\#2\#1; UFU-184\#2\#1; UFU- \\
& 199\#5\#1\#1; UFU-184\#2\#5\#1; UFU-206\#1\#3\#1; \\
& UFU-199\#6\#1\#1; UFU-75\#1\#1\#1; UFU-189\#2\#1\#1 \\
\hline \multirow{2}{*}{ Traditional index } & UFU-199\#1\#1\#1; UFU-199\#6\#1\#1; UFU-199\#6\#2\#1; UFU-75\#2\#2\#1; UFU-199\#2\#1\#1; UFU-199\#2\#2\#1; UFU- \\
& 184\#2\#1; UFU-199\#5\#1\#1; UFU-184\#2\#5\#1; UFU-206\#1\#3\#1; UFU-184\#2\#3\#1; UFU-75\#1\#3\#1 \\
\hline \multirow{2}{*}{ Index of the sum of ranks } & UFU-199\#1\#1\#1; UFU-199\#6\#1\#1; UFU-199\#6\#2\#1; UFU-75\#2\#2\#1; UFU-199\#2\#1\#1; UFU-184\#2\#3\#1; UFU- \\
& 199\#2\#2\#1; UFU-75\#1\#3\#1; UFU-199\#5\#1\#1; UFU-184\#2\#5\#1; UFU-7\#1\#1\#1; UFU-75\#1\#1\#1 \\
\hline \multirow{2}{*}{ Base index } & UFU-199\#1\#1\#1; UFU-199\#6\#1\#1; UFU-199\#6\#2\#1; UFU-75\#2\#2\#1; UFU-199\#2\#1\#1; UFU-199\#2\#2\#1; UFU- \\
& 184\#2\#3\#1; UFU-75\#1\#3\#1; UFU-184\#2\#1; UFU-7\#1\#1\#1; UFU-199\#2\#3\#1; UFU-184\#2\#1\#1 \\
\hline
\end{tabular}


Mulamba \& Mock (1978) for the lettuce crop (Peixoto et al., 2020) and the indices of Smith (1936) and Hazel (1943) and Mulamba \& Mock (1978) for strawberry (Fragaria $\times$ ananassa) (Vieira et al., 2017), confirming the results obtained in the present work.

The index of Smith (1936) and Hazel (1943) selected $75 \%$ of the genotypes that were selected by the index of Willians (1962). The difference between the two indices lies in the selection of genotypes UFU199\#5\#1\#1, UFU-184\#2\#5\#1, and UFU-206\#1\#3\#1 by the index of Smith (1936) and Hazel (1943); and UFU$7 \# 1 \# 1 \# 1$, UFU-199\#2\#3\#1, and UFU-184\#2\#1\#1 by the index of Willians (1962). All indices analyzed in the present study selected genotypes UFU-199\#1\#1\#1, UFU-199\#6\#1\#1，UFU-199\#6\#2\#1，UFU-75\#2\#2\#1, UFU-199\#2\#1\#1, and UFU-199\#2\#2\#1. The index estimators are different so the choice of genotypes is not similar. However, when this happens, there is a greater confidence in choosing the best lines to follow in the breeding process. The base index of Willians (1962) corresponds to that of Smith (1936) and Hazel (1943) when phenotypic variances and covariances are mainly determined by genetic factors (Cruz et al., 2014).

The indices of Smith (1936) and Hazel (1943) and of Mulamba \& Mock (1978), together with direct selection, were $66.66 \%$ coherent regarding the selected genotypes - UFU-199\#1\#1\#1, UFU-199\#6\#1\#1, UFU199\#6\#2\#1, UFU-75\#2\#2\#1, UFU-199\#2\#1\#1, UFU199\#2\#2\#1, UFU-199\#5\#1\#1, and UFU-184\#2\#5\#1. Describing the same germplasm bank studied in this research but through the univariate analysis, Maciel et al. (2019b) observed excellent agronomic and nutritional characteristics in the same genotypes. This result suggests a promising use of such lines in future breeding programs. When evaluating selection indices on strawberries, Vieira et al. (2017) concluded that the indices of Mulamba \& Mock (1978) and Smith (1936) and Hazel (1943) provided the highest gains, confirming the results of the present study.

\section{Conclusions}

1. The traditional index of Smith \& Hazel and the sum of ranks index of Mulamba \& Mock provide the highest selection gains for biofortified red leaf lettuce (Lactuca sativa var. crispa).

2. The traditional index of Smith \& Hazel, the sum of ranks index of Mulamba \& Mock, and the direct selection method agree in selecting genotypes UFU199\#1\#1\#1, UFU-199\#6\#1\#1, UFU-199\#6\#2\#1, UFU75\#2\#2\#1, UFU-199\#2\#1\#1, UFU-199\#2\#2\#1, UFU199\#5\#1\#1, and UFU-184\#2\#5\#1.

3. The coefficient of genotypic determination for leaf count, anthocyanin content, bolting, and the soil plant analysis development index has a high magnitude, suggesting a high capacity of the progeny in transferring these characteristics to their offspring.

4. Plant diameter and bolting produce a positive direct effect on the main variable, leaf count, which shows the adaptation of the genetic material to the environment.

\section{Acknowledgments}

To Fundação de Amparo à Pesquisa do Estado de Minas Gerais (Fapemig), to Conselho Nacional de Desenvolvimento Científico e Tecnológico (CNPq), to Universidade Federal de Uberlândia (UFU), and to Pró-Reitoria de Pós-Graduação e Pesquisa (PROPP), for their financial and administrative support; and to Coordenação de Aperfeiçoamento de Pessoal de Nível Superior (Capes), for financing, in part, this study (Finance Code 001).

\section{References}

AZEVEDO, A.M.; ANDRADE JÚNIOR, V.C. de; CASTRO, B.M. de C. e; OLIVEIRA, C.M. de; PEDROSA, C.E.; DORNAS, M.F.S.; VALADARES, N.R. Parâmetros genéticos e análise de trilha para o florescimento precoce e características agronômicas da alface. Pesquisa Agropecuária Brasileira, v.49, p.118-124, 2014. DOI: https://doi.org/10.1590/S0100-204X2014000200006.

BIZARI, E.H.; VAL, B.H.P.; PEREIRA, E. de M.; MAURO, A.O. Di; UNÊDA-TREVISOLI, S.H. Selection indices for agronomic traits in segregating populations of soybean. Revista Ciência Agronômica, v.48, p.110-117, 2017.

CASSETARI, L.S.; GOMES, M.S.; SANTOS, D.C.; SANTIAGO, W.D.; ANDRADE, J.; GUIMARÃES, A.C.; SOUZA, J.A.; CARDOSO, M.G.; MALUF, W.R.; GOMES, L.A. $\beta$-carotene and chlorophyll levels in cultivars and breeding lines of lettuce. Acta Horticulturae, v.1083, p.469-473, 2015. DOI: https://doi.org/10.17660/ActaHortic.2015.1083.60.

CECCHERINI, G.J.; LIMA, T.J.L. de; SALA, F.C. Different tray cell volumes for lettuce grown in conventional and hydroponic system. Ciência Rural, v.50, e20190491, 2020. DOI: https://doi.org/10.1590/0103-8478cr20190491.

CHOPRA, S.; RANJAN, P.; SINGH, V.; KUMAR, S.; ARORA, M.; HASAN, M.S.; KASIRAJ, R.; SURYANSH; KAUR, D.; VIKRAM, N.K.; MALHOTRA, A.; KUMARI, A.; KLANIDHI, 
K.B.; BAITHA, U. Impact of COVID-19 on lifestyle-related behaviours- a cross-sectional audit of responses from nine hundred and ninety-five participants from India. Diabetes \& Metabolic Syndrome: Clinical Research \& Reviews, v.14, p.2021-2030, 2020. DOI: https://doi.org/10.1016/j.dsx.2020.09.034.

CRUZ, C.D. Genes: a software package for analysis in experimental statistics and quantitative genetics. Acta Scientiarum. Agronomy, v.35, p.271-276, 2013. DOI: https://doi.org/10.4025/actasciagron.v35i3.21251.

CRUZ, C.D.; CARNEIRO, P.C.S.; REGAZZI, A.J. Modelos biométricos aplicados ao melhoramento genético. 3.ed. Viçosa: Ed. da UFV, 2014. v.2, 668p.

DIAMANTE, M.S.; SEABRA JÚNIOR, S.; INAGAKI, A.M.; SILVA, M.B. da; DALLACORT, R. Produção e resistência ao pendoamento de alfaces tipo lisa cultivadas sob diferentes ambientes. Revista Ciência Agronômica, v.44, p.133-140, 2013. DOI: https://doi.org/10.1590/S1806-66902013000100017.

FILGUEIRA, F.A.R. Novo manual de olericultura: agrotecnologia moderna na produção e comercialização de hortaliças. 3.ed. rev. e ampl. Viçosa: UFV, 2013. 421p.

FRANCIS, F.J. Analysis of anthocyanins. In: MARKAKIS, P. (Ed.). Anthocyanins as food colors. New York: Academic Press, 1982. p.181-207. DOI: https://doi.org/10.1016/B978-0-12-4725508.50011-1.

HAZEL, L.N. The genetic basis for constructing selection indexes. Genetics, v.28, p.476-490, 1943. DOI: https://doi.org/10.1093/ genetics/28.6.476.

LEITE, W. de S.; PAVAN, B.E.; MATOS FILHO, C.H.A.; ALCANTARA NETO, F. de; OLIVEIRA, C.B. de; FEITOSA, F.S. Estimativas de parâmetros genéticos, correlações e índices de seleção para seis caracteres agronômicos em linhagens F8 de soja. Comunicata Scientiae, v.7, p.302-310, 2016. DOI: https://doi.org/10.14295/cs.v7i3.1176.

MACIEL, G.M.; GALLIS, R.B. de A.; BARBOSA, R.L.; PEREIRA, L.M.; SIQUIEROLI, A.C.S.; PEIXOTO, J.V.M. Image phenotyping of inbred red lettuce lines with genetic diversity regarding carotenoid levels. International Journal of Applied Earth Observation and Geoinformation, v.81, p.154-160, 2019b. DOI: https://doi.org/10.1016/j.jag.2019.05.016.

MACIEL, G.M.; SIQUIEROLI, A.C.S.; GALLIS, R.B. de A.; PEREIRA, L.M.; SALES, V.F. BG a Biofort. Depositante: Universidade Federal de Uberlândia. BR n. 512019002403-6. Depósito: 01 fev. 2019. Concessão: 23 out. 2019a.

MULAMBA, N.N.; MOCK, J.J. Improvement of yield potential of the Eto Blanco maize (Zea mays L.) population by breeding for plant traits. Egyptian Journal of Genetics and Citology, v.7, p.40-51, 1978.

OLIVEIRA, A.H.G. de; MACIEL, G.M.; SIQUIEROLI, A.C.S.; JACINTO, A.C.P.; SILVEIRA, A.J. da; SILVA, E.C. da. Estimates of genetic parameters of pigments and agronomic traits in green and purple lettuce. Ciência e Agrotecnologia, v.43, e013219, 2019. DOI: https://doi.org/10.1590/1413-7054201943013219.

PEIXOTO, J.V.M.; MACIEL, G.M.; SIQUIEROLI, A.C.S.; PEREIRA, L.M.; LUZ, J.M.Q.; MARQUES, D.J. Comparison between non-parametric indexes in the selection of biofortified curly lettuce. Comunicata Scientiae, v.11, e3351, 2020. DOI: https://doi.org/10.14295/cs.v11i.3351.

PIMENTEL-GOMES, F. Curso de estatística experimental. 15.ed. Piracicaba: Fealq, 2009. 451p.

PINTO, A.A.; SANTANA, L.D.; CAMARA, F.T. da; RODRIGUES, W.Á.D.; COSTA, M.N.F. da; PENHA FILHO, N. da. Desenvolvimento e produção de alface crespa utilizando culturas para sombreamento lateral. Revista Verde de Agroecologia e Desenvolvimento Sustentável, v.12, p.655-660, 2017. DOI: https://doi.org/10.18378/rvads.v12i4.4840.

RAMALHO, M.A.P.; ABREU, A. de F.B.; SANTOS, J.B. dos; NUNES, J.A.R. Aplicações da genética quantitativa no melhoramento de plantas autógamas. Lavras: UFLA, 2012. 522p.

SALA, F.C.; COSTA, C.P. da. Retrospectiva e tendência da alfacicultura brasileira. Horticultura Brasileira, v.30, p.187-194, 2012. DOI: https://doi.org/10.1590/S0102-05362012000200002.

SANTI, A.; SCARAMUZZA, W.L.M.P.; NEUHAUS, A.; DALLACORT, R.; KRAUSE, W.; TIEPPO, R.C. Desempenho agronômico de alface americana fertilizada com torta de filtro em ambiente protegido. Horticultura Brasileira, v.31, p.338-343, 2013. DOI: https://doi.org/10.1590/S0102- 05362013000200027.

SILVA, I.G. da; CASTOLDI, R.; CHARLO, H.C. de O.; MIRANDA, M. de S.; NUNES, T.D.C.; COSTA, L.L.; LEMES, E.M. Prediction of genetic gain in sweet corn using selection indexes. Journal of Crop Science and Biotechnology, v.23, p.191-196, 2020. DOI: https://doi.org/10.1007/s12892-019-03340 .

SILVA, O.M. dos P. da; LOPES, W. de A.R.; NUNES, G.H. de S.; NEGREIROS, M.Z. de; ESPÍNDOLA SOBRINHO, J. Adaptability and phenotypic stability of lettuce cultivars in a semiarid region. Revista Caatinga, v.32, p.552-558, 2019. DOI: https://doi.org/10.1590/1983-21252019v32n228rc.

SMITH, H.F. A discriminant function for plant selection. Annals of Eugenics, v.7, p.240-250, 1936. DOI: https://doi.org/10.1111/j.1469-1809.1936.tb02143.x.

SOIL SURVEY STAFF. Keys to soil taxonomy. $12^{\text {th }}$ ed. Washington: USDA, 2014. 328p. Available at: $<$ https://www. nrcs.usda.gov/wps/portal/nrcs/detail/soils/survey/class/ taxonomy/?cid=nrcs142p2_053580>. Accessed on: Oct. 102020.

SOUSA, C.S. de; BONETTI, A.M.; GOULART FILHO, L.R.; MACHADO, J.R. de A.; LONDE, L.N.; BAFFI, M.A.; RAMOS, R.G.; VIEIRA, C.U.; KERR, W.E. Divergência genética entre genótipos de alface por meio de marcadores AFLP. Bragantia, v.66, p.11-16, 2007. DOI: https://doi.org/10.1590/S000687052007000100002 .

SYTAR, O.; ZIVCAK, M.; BRUCKOVA, K.; BRESTIC, M.; HEMMERICH, I.; RAUH, C.; SIMKO, I. Shift in accumulation of flavonoids and phenolic acids in lettuce attributable to changes in ultraviolet radiation and temperature. Scientia Horticulturae, v.239, p.193-204, 2018. DOI: https://doi.org/10.1016/j. scienta.2018.05.020.

THAKUR, M.; KUMAR, R.; KUMAR, S. Studies on genetic variability, correlation and path analysis in lettuce (Lactuca sativa 
L.) under protected conditions. Journal of Applied and Natural Science, v.8, p.1924-1930, 2016. DOI: https://doi.org/10.31018/ jans.v8i4.1064.

VIEIRA, S.D.; SOUZA, D.C. de; MARTINS, I.A.; RIBEIRO, G.H.M.R.; RESENDE, L.V.; FERRAZ, A.K.L.; GALVÃO, A.G.; RESENDE, J.T.V. de. Selection of experimental strawberry (Fragaria $\mathrm{x}$ ananassa) hybrids based on selection indices.
Genetics and Molecular Research, v.16, p.1-11, 2017. DOI: https://doi.org/10.4238/gmr16019052.

WILLIANS, J.S. The evaluation of a selection index. Biometrics, v.18, p.375-393, 1962. DOI: https://doi.org/10.2307/2527479.

ZHANG, Y.Z.; XU, S.Z.; CHENG, Y.W.; YA, H.Y.; HAN, J.M. Transcriptome analysis and anthocyanin-related genes in red leaf lettuce. Genetics and Molecular Research, v.15, p.1-11, 2016. DOI: https://doi.org/10.4238/gmr.15017023. 